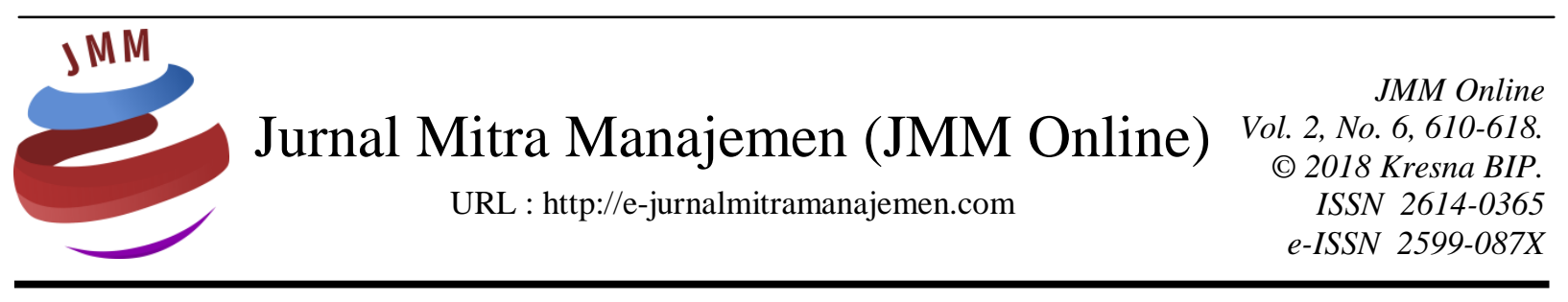

\title{
PEMAHAMAN PENTINGNYA KEMASAN TERHADAP PELAKU USAHA BERDASARKAN RENTANG VARIASI LAMA USAHA
}

\author{
Amarul 1), Sukirno ${ }^{2)}$, Andari ${ }^{3)}$ \\ Universitas Serang Raya
}

INFORMASI ARTIKEL

Dikirim : 18 Oktober 2018

Revisi pertama : 24 Oktober 2018

Diterima : 25 Oktober 2018

Tersedia online : 01 Desember 2018

Kata Kunci : Kemasan Produk, Lama Usaha

Email: amarulunsera@gmail.com

\section{ABSTRAK}

Penelitian ini bertujuan untuk mengetahui tingkat pemahaman tentang kemasan pada pelaku usaha mikro kecil dan menengah.

Analisis yang digunakan yaitu deskriptif dengan data kuantitatif. Dengan menggunakan kuesioner sabagai alat intrumennya dimana jumlah sampelnya adalah 101 para pelaku uaha dengan rentang waktu lama usaha yang berbeda.

Hasil penelitian menunjukan bahwa 91,09\% para pelaku usaha yang telah melakukan kemasan pada produknya dan $8,91 \%$ yang belum memberikan kemasan pada produknya dan para pelaku usaha yang nilai presentase nya lebih tnggi yaitu pada lawa waktu usaha kurang dari 2 tahun yaitu 96,55\% dan nilai presentase nya rendah yaitu pada lama waktu usaha lebih dari 10 tahun sebesar $75 \%$. 


\section{PENDAHULUAN \\ Latar Belakang}

Perkembangan sektor UKM yang demikian pesat memperlihatkan bahwa terdapat potensi yang besar jika hal ini dapat dikelola dan dikembangkan dengan baik tentunya akan dapat mewujudkan usaha menengah yang tangguh. salah satu faktor yang menjadi penghambat dalam pengembangan UKM terletak pada proses pemasaran tidak sedikit para pelaku UKM dalam menjalankan usahanya tidak menggunakan proses pemasaran dengan baik, yang terpikir oleh para pelaku adalah bagaimana dapat menjual produk nya kepada masyarakat tanpa memperhitungkan proses pemasarannya. Proses pemasaran yang baik maka akan menghasilkan yang baik pula.

Saat ini kemasan telah menjadi alat pemasaran yang penting, kemasan yang bila dirancang dengan baik dapat memberikan nilai jual bagi konsumen dan nilai promosi bagi produsen, banyak faktor telah meningkatkan penggunaan kemasan sebagai alat pemasaran. Banyak perusahaan yang sangat memperhatikan pembungkus suatu barang sebab konsumen menganggap bahwa fungsi pembungkus tidak hanya pembungkus. Pengemas merupakan proses yang berkaitan dengan perancangan dan pembuatan wadah atau pembungkus untuk suatu produk (Tjiptono, 2002 :151).

Disadari atau tidak bahwa para pelaku UKM di Kabupaten Serang tidak mempermasalahkan mengenai kemasan (packaging) pada produk yang dihasilkannya, mereka hanya berpikir sederhana bagaimana produk yang dibuatnya dapat terjual, dan mendapatkan keuntungan. Ada beberapa produk UMKM Kabupaten Serang yang dikemas dengan biasa saja, ini menunjukkan bahwa adanya para pelaku usaha yang tidak mengerti dengan arti dari kemasan, walaupun para pengusaha UMKM tersebut telah menjalankan usahanya dengan lebih dari 2 tahun.

Menurut Klimchuk \& Krasovec (2007), pemasar harus sekreatif mungkin dalam penciptaan desain kemasan, karena desain kemasan yang menarik dan unik dapat memacu perilaku impulsive buying.

Hasil penelitian Leni Nuryanti (2008) menunjukan bahwa kemasan memberikan pengaruh positif terhadap keputusan pembelian. Th Susetyarsi (2012) hasil penelitiannya bahwa bentuk kemasan memberikan pengaruh yang besar terhadap keputusan pembelian. Komalasari (2010) menyatakan bahwa bentuk berpengaruh positif terhadap minat beli konsumen. Nasution (2010). Tommy Kurniawan Njoto (2016) menyatakan bahwa bentuk berpengaruh positif terhadap minat beli konsumen. Desain kemasan dapat berpengaruh signifikan terhadap keputusan pembelian.

Dengan demikian dapat dikatakan bahwa kemasan sebagai salah satu ujung tombak pemasaran bukan sekedar bungkus, tetapi bagian dari daya tarik bagi konsumen dan menjadi pembeda dalam produk serta menciptakan nilai jual bagi produk. Kemasan yang baik dapat menciptakan nilai kenyamanan konsumen dan nilai promosi produsen.

\section{Rumusan Masalah}

Berdasarkan latar belakang diatas, maka rumusan masalah dalam penelitian ini adalah sejauhmana tingkat pemahaman para pelaku usaha terhadap kemasan berdasarkan rentang waktu usaha di Kabupaten Serang. 


\section{Tujuan Penelitian}

Sesuai dengan masalah penelitian yang dirumuskan diatas, maka yang menjadi tujuan dalam penelitian ini adalah untuk menganalisis tingkat pemahaman para pelaku usaha terhadap kemasan berdasarkan rentang waktu usaha di Kabupaten Serang.

\section{Manfaat Penelitian}

Penelitian ini diharapkan dapat memberikan manfaat secara teoritis dan secara praktis bagi para pelaku usaha untuk mendapatkan pemahaman lebih mendalam mengenai merek, kemasan dan sertifikasi halal.

1. Secara Teoritis

Penelitian ini diharapkan dapat memberikan manfaat secara teoritis dalam pengembangan ilmu manajemen, sehingga dapat digunakan untuk penelitian selanjutnya terutama untuk mendapatkan pemahaman lebih mendalam mengenai kompleksitas permasalahan, Sehingga para pelaku UKM dapat mengelola usaha nya lebih maju lagi.

2. Secara Praktis

Hasil penelitian ini diharapkan dapat memberikan pembelajaran dalam bentuk studi kasus bagi para pelaku usaha untuk mendapatkan pemahaman lebih mendalam mengenai masalah pemasaran.

\section{KAJIAN PUSTAKA}

Kotler dan Amstrong (2012) mendefinisikan "packaging involves designing and producing the container or wrapper for a product"yang artinya adalah proses kemasan melibatkan kegiatan mendesain dan memproduksi, fungsi utama dari kemasan sendiri yaitu untuk melindungi produk agar produk tetap terjaga kualitasnya.

Menurut Titik Wijayanti (2012), Kemasan mempunyai tujuan dan fungsi dalam pembuatan produk, yaitu:

a. Memperindah produk dengan kemasan yang sesuai kategori produk.

b. Memberikan keamanan produk agar tidak rusak saat dipajang ditoko.

c. Memberikan keamanan produk pada saat pendistribusian produk.

d. Memberikan informasi pada konsumen tentang produk itu sendiri dalam bentuk pelabelan.

e. Merupakan hasil desain produk yang menunjukan produk tersebut.

Menurut Deliya, \& Parmar (2012), ada enam variabel yang harus dipertimbangkan oleh produser dan desainer saat membuat kemasan efisien, yaitu bentuk, ukuran, warna, grafis, material dan rasa. Demikian pula, Kotler (2003) dalam Deliya, \& Parmar, (2012) yang membedakan enam elemen yang menurutnya harus dievaluasi ketika menggunakan keputusan kemasan, yaitu ukuran, bentuk, bahan, warna, teks dan merek. Namun menurut penulis, dari semua variabel tersebut, warna dan bentuk lebih penting dan biasanya paling banyak diperhatikan, khususnya oleh anak-anak. Namun ada pula yang mengatakan bahwa gambar juga memiliki peran dalam kemasan. Deliya, \& Parmar (2012) menemukan bahwa ketika adanya pengabaian terhadap tanda-tanda non-verbal seperti warna, maka perhatian terhadap tanda-tanda verbal dapat ditingkatkan. Gambar pada kemasan ditekankan untuk menarik perhatian, terutama ketika konsumen sangat tidak akrab dengan merek 
produk tersebut. Mahrinasari dan Indriani (2009) mendefinisikan kemasan merupakan kegiatan yang berorientasi kepada produksi dan diadakan khusus untuk memperoleh maslahat perlindungan dan kemudahan. Nasution (2010) menyatakan bahwa warna berpengaruh positif dan signifikan terhadap minat beli konsumen.

Menurut Kotler dan Keller (2012), Kemasan yang baik dapat membangun ekuitas merek dan mendorong penjualan. Beberapa faktor yang memiliki kontribusi penggunaan kemasan sebagai alat pemasaran :

a. Swalayan, kemasan yang efektif melaksanakan tugas dalam penjualan: menarik perhatian, menggambarkan fitur produk, menciptakan keyakinan konsumen, dan membuat kesan menyenangkan.

b. Kekayaan Konsumen, peningkatan kekayaan konsumen membuat mereka bersedia membayar lebih besar untuk kenyamanan, penampilan, keandalan, dan gengsi kemasan yang lebih baik.

c. Perusahaan dan Citra Merek, kemasan mempunyai peran terhadap pengakuan segera atas perusahaan atau merek.

d. Peluang Inovasi, kemasan yang inovatif dapat membawa manfaat besar bagi konsumen dan laba bagi para produsen.

Pembungkus tidak hanya merupakan pelayanan tetapi juga sebagai salesman dan pembawa kepercayaan, dimana suatu pembungkus merupakan penglihatan akhir dari konsumen yang dapat dipercaya" (Alma, 2007:159).

Menurut Bukhori Alam (2007:146) Adanya pengemasan suatu produk dapat menguntungkan bagi pihak produsen. Keuntungan tersebut diantaranya sebagai berikut:

1. Melindungi barang-barang yang dibungkusnya sewaktu barang-barang tersebut bergerak melalui proses marketing.

2. Memudahkan pedagang eceran untuk membagi-bagi atau memisahkan barang tersebut.

3. Untuk mempertinggi nilai isinya dengan daya tarik yang ditimbulkan oleh pembungkus, sehingga menimbulkan ciri-ciri khas produk tersebut.

4. Untuk identitas, mudah dikenal, karena adanya label atau merek yang tertera pada pembungkus.

5. Pembungkus dapat digunakan sebagai alat komunikasi karena membawa berita atau catatan mengenai produk itu.

6. Pembungkus sebagai salesmen diam, seperti supermarket. Disini para pembeli tidak dilayani oleh salesmen tetapi pembeli cukup mengetahui dan memilih barangnya sendiri dengan membaca label pada pembungkus.

7. Selain packaging yang baik, perusahaan juga harus membuat kemasan yang indah untuk menarik konsumen.

\section{METODE PENELITIAN}

Jenis Penelitian

Penelitian yang dilakukan merupakan analisis deskriptif terhadap data kuantitatif untuk mengetahui informasi kepentingan kemasan dimata pelaku usaha. Penelitian deskriptif merupakan jenis penelitian yang menganalisa data dengan cara mendiskripsikan atau menggambarkan data yang terkumpul sebagaimana adanya tanpa bermaksud membuat kesimpulan yang berlaku untuk umum atau generalisasi 
(Sugiyono, 2008). Dengan kata lain, statistika deskriptif ini merupakan fase yang membicarakan mengenai penjabaran dan penggambaran termasuk penyajian data. Dalam fase ini dibahas mengenai ukuran-ukuran statistik seperti ukuran pusat, ukuran sebaran, dan ukuran lokasi dari persebaran / distribusi data.

Selanjutnya jumlah sampel 101 pelaku usaha dengan rentang lama operasi yang berbeda. Kemudian melakuan penyebaran angket dan analisis data dengan pendekatan statistik agar dapat melakukan interpretasi hasil penelitian. Pada penelitian ini juga sampel pelaku usaha yang dijadikan responden adalah para pengusaha di wilayah Provinsi Banten, khususnya di Kabupaten Serang.

\section{Tempat dan Waktu Penelitian}

Penelitian ini dilakukan kepada para pelaku usaha mikro kecil menengah di Wilayah Kabupaten Serang. Sedangkan waktu penelitian dilakukan dari bulan April sampai dengan bulan Agustus 2018.

\section{Teknik Pengumpulan Data}

Adapun teknik pengumpulan data yang digunakan untuk memperoleh data-data yang diperlukan dengan cara-cara sebagai berikut:

1. Penelitian Kepustakaan (Library Research), penelitian dengan pengkajian bukubuku dan sumber-sumber lain yang berhubungan dengan masalah yang diteliti dan pengumpulan datanya dari literatur-literatur tersebut.

2. Penelitian Lapangan (Field Research) yaitu penelitian yang dilakukan dengan cara mendatangi tempat yang diteliti dan pengumpulan datanya langsung mendekati responden dengan cara:

a. Wawancara yaitu mengadakan Tanya jawab langsung dengan orang-orang yang berhubungan dengan masalah yang akan diteliti.

b. Dokumentasi yaitu Mencatat data-data yang ada kaitannya dengan masalah yang diteliti dari sumber-sumber tertulis yang ada di perusahaan.

c. Kuesioner yaitu membuat daftar pernyataan yang berhubungan dengan objek yang sedang diteliti, yang kemudian disebarkan kepada para konsumen dan hasil dari pernyataan atau jawaban tersebut kemudian dikumpulkan kembali.

\section{HASIL PENELITIAN DAN PEMBAHASAN \\ Hasil Penelitian}

Berdasarkan hasil pengolahan data statistik maka diperoleh beberapa rentang nilai lamanya operasi usaha seperti diperlihatkan pada tabel dibawah ini.

Tabel 1. Karakteristik Responden Berdasarkan Lamanya Usaha

\begin{tabular}{|l|l|l|}
\hline Lama Usaha & Jumlah & Persentase \\
\hline$<2$ tahun & 29 & 28,71 \\
\hline$>=2$ tahun dan $<5$ tahun & 39 & 38,61 \\
\hline$>=5$ tahun dan $<10$ tahun & 17 & 16,83 \\
\hline$>=10$ tahun & 8 & 7,92 \\
\hline Blank & 8 & 7,92 \\
\hline
\end{tabular}

Sumber : Hasil Penelitian, diolah (2018) 
Sebagian besar responden yang mengisi angket sudah menjalankan usahanya antara 1 sampai kurang lebih 5 tahun. Selebihnya responden yang terlibat dalam penelitian ini telah menjalankan usahanya antara 5 sampai 10 tahun. Jika dilihat berdasarkan tabel dan gambar diatas dapat di ketahui bahwa responden dalam penelitian ini didominasi oleh responden yang masa usahanya diatas 2 tahun dan dibawah 5 tahun yaitu sebesar 38,61\% sedangkan yang paling terkecil adalah responden yang masa usahanya dibawah 8 tahun 7,92\% dan tanpa mengisi blank $7,92 \%$, yang dikarenakan dalam angket pertanyaan tidak membirikan informasi.

Berdasarkan data bahwa responden dalam penelitian ini didominasi oleh responden yang berjenis kelamin perempuan dengan angka presentasi 74,26\% dan jika dibandingkan dengan angka presentasi responden perempuan, maka hanya terpaut sebesar 48,52\%, maka dapat disimpulkan bahwa dari 101 pengusaha di dominasi oleh jenis kelamin perempuan. Berikut adalah tabel karakteristik menurut jenis kelamin responden.

\section{Tabel 2. Karakteristik Responden Berdasarkan Jenis Kelamin}

\begin{tabular}{|l|l|l|}
\hline Jenis Kelamin & Jumlah & Persentase \\
\hline Laki-laki & 26 & 25,74 \\
\hline Perempuan & 75 & 74,26 \\
\hline Total & 101 & 100,00 \\
\hline
\end{tabular}

Sumber : Hasil Penelitian, diolah (2018)

Dari keseluruhan responden dan berdasarkan hasil analisis yang dilakukan juga diketahui bahwa 91,09\% para pelaku usaha yang telah melakukan kemasan pada produknya dan $8,91 \%$ yang belum memberikan kemasan pada produknya. Dapat dilihat pada tabel dibawah ini

Tabel 3. Responden Penggunaan Kemasan

\begin{tabular}{|l|l|l|}
\hline Kemasan & Jumlah & $\%$ \\
\hline Ada & 92 & 91,09 \\
\hline tidak ada & 9 & 8,91 \\
\hline Total & 101 & 100 \\
\hline
\end{tabular}

Sumber : Hasil Penelitian, diolah (2018)

Variabel kemasan diukur melalui 3 indikator yaitu desain (K1), mutu (K2, K3), dan inovasi (K4). Hasil jawaban responden dalam bentuk skor rata-rata selanjutnya ditampilkan pada tabel berikut ini.

Tabel 4. Descriptive Statistics

\begin{tabular}{|l|l|l|l|l|l|}
\hline & & Minimum & Maximum & Mean & $\begin{array}{l}\text { Std. } \\
\text { Deviation }\end{array}$ \\
\hline K1 & 101 & 2,00 & 5,00 & 4,5941 &, 55097 \\
K2 & 101 & 1,00 & 5,00 & 4,4554 & 71449 \\
K3 & 101 & 2,00 & 5,00 & 4,3663 &, 57832 \\
K4 & 101 & 2,00 & 5,00 & 4,3366 &, 75203 \\
Valid N (listwise) & 101 & & & & \\
\hline
\end{tabular}

Sumber : Hasil Penelitian, diolah (2018)

Berdasarkan tabel tersebut diketahui bahwa nilai rata-rata dari setiap butir pertanyaan yang berhubungan dengan kemasan adalah sebesar 4,438 sedangkan rata- 
rata untuk setiap indikator adalah 4,59 untuk indikator desain, indikator mutu ratarata 4,41 dan indikator inovasi rata rata 4,33. Untuk rata-rata tertinggi dari setiap instrumen yaitu pada K1 (Desain kemasan dengan baik dapat menciptakan nilai promosi bagi produsen) sebesar 4,59, ini menunjukan bahwa persepsi para pelaku usaha memahami desain kemasan dapat dijadikan tempat untuk promosi. Untuk ratarata terendah dari setiap instrumen yaitu K4 (Pengemasan inovatif dapat memberikan manfaat laba bagi produsen) sebesar 4,33. Ini menunjukan bahwa persepsi para pelaku masih minim dalam melakukan inovasi terhadap kemasan dalam memasarkan produknya.

Bila kita memperhatikan dari segi lama waktu usaha dari 101 responden, para pelaku usaha telah menggunakan kemasan pada produknya dapat dilihat pada tabel dibawah ini :

Tabel 5. Data Responden yang Menggunakan Kemasan

\begin{tabular}{|c|c|c|c|c|c|}
\hline \multirow{2}{*}{ Waktu Usaha } & \multirow{2}{*}{$\begin{array}{l}\text { Jumlah } \\
\text { Responden } \\
\end{array}$} & \multicolumn{2}{|c|}{ Kemasan } & \multicolumn{2}{|l|}{$\%$} \\
\hline & & Ada & tidak & Ada & tidak \\
\hline$<2$ tahun & 29 & 28 & 1 & 96,55 & 3,45 \\
\hline$>=2$ tahun dan $<5$ tahun & 39 & 37 & 2 & 94,87 & 5,13 \\
\hline$>=5$ tahun dan $<10$ tahun & 17 & 15 & 2 & 88,24 & 11,76 \\
\hline$>=10$ tahun & 8 & 6 & 2 & 75,00 & 25,00 \\
\hline Blank & 8 & 6 & 2 & 75,00 & 25,00 \\
\hline Total & 101 & 92 & 9 & & \\
\hline
\end{tabular}

Sumber : Hasil Penelitian, diolah (2018)

Berdasarkan tabel diatas bawah para pelaku usaha yang menjalankan usahanya kurang 2 tahun dari 101 responden terdapat 29 pelaku usaha dan 96,55\% telah melakukan kemasan, waktu usaha antara lebih dari 2 tahun dan kurang dari 5 tahun terdapt 39 pelaku usaha dan $94,87 \%$ telah melakukan pengemasan, lamanya usaha antara lebih dari 5 tahun dan kurang dari 10 tahun sebanyak 17 pelaku usaha dan $88,24 \%$ telah melakukan pengemasan dan lama usaha lebih dari 10 tahun terdapat pelaku usaha dan $75 \%$ telah melakukan pengemasan pada produknya.

\section{Pembahasan}

Dari uraian diatas dapat terlihat bahwa para pelaku usaha yang nilai presentase nya lebih tnggi yaitu pada lawa waktu usaha kurang dari 2 tahun yaitu 96,55\% dan nilai presentase nya rendah yaitu pada lama waktu usaha lebih dari 10 tahun yaitu $75 \%$. Sedangkan berdasarkan hasil penelitian sebelumnya Vishnu, \& Ahmed (2014), menyatakan bahwa kemasan dapat menarik perhatian konsumen terhadap merek tertentu, meningkatkan citra, dan merangsang persepsi konsumen tentang produk. Kemudian, kemasan juga menyampaikan nilai khas suatu produk (Raheem, Vishnu, \& Ahmed, 2014). Nasution (2010) menyatakan bahwa semua variabel bebas (desain kemasan) yang terdiri dari ukuran, bentuk, warna, bahan, logo dan label secara simultan berpengaruh positif terhadap minat beli konsumen 


\section{KESIMPULAN \\ Kesimpulan}

Persepsi para pelaku usaha terhadap kemasan dapat dikatakan baik dan 91,09\% para pelaku usaha telah memberikan kemasan kepada produknya, walaupun kemasan yang dilakukan oleh para pengusaha masih terbilang sederhana yang sifatnya untuk menghindari dari kotoran.

\section{Saran}

Dari penjelasan diatas bahwa dapat disimpulkan bahwa para pelaku usaha ini selalu diberikan motivasi dan pemahaman lebih lanjut terkait dengan kemasan baik dilakukan oleh pemerintah ataupun pihak yang terkait, sehingga setiap produk yang dihasilkan oleh para pengusaha dapat bersaing dengan produk yang beredar di pasar, serta dapat menumbuhkan minat beli konsumen

\section{DAFTAR PUSTAKA}

B. Lena Nuryanti, Anisa Yunia Rahman. 2008, "Pengaruh variasi dan kemasan produk terhdap keputusan pembelian Teh Kotak Ultra Jaya" Strageik (Journal of business Managemen \& Enterpreneur Education). Vol 7 No. 14 ISSN 14121946.

Buchari, Alma. 2002. Manajemen Pemasaran dan Pemasaran Jasa. Bandung: Alfabeta.

Deliya, M. M., \& Parmar, M. B. J. 2012. Role of Packaging on Consumer Buying Behavior Patan District. Global Journal of Management and Business Research, 12 (10).

Klimchuck, Marianne R., \& Krasovec, Sandra A. 2007. Desain Kemasan: Perencanaan Merek Produk yang Berhasil Mulai dari Konsep sampai Penjualan (penerjemah: Bob Sabran). Erlangga, Jakarta.

Kotler, \& Keller. 2012. Manajemen Pemasaran Edisi Kelima Belas Jilid Satu. Jakarta: Indek

Mahrinasari dan Indriani, Cori. 2009. Analisis Pengaruh Perubahan Kemasan Sunsilk terhadap Preferensi Pembelian Konsumen (Studi pada Mahasiswa Universitas Lampung). Jurnal Bisnis dan Manajemen. Vol. 5 No.2, Januari 2009

Nasution, Uthe Ch. 2010. Pengaruh Desain Kemasan Terhadap Minat Beli Konsumen Dalam Membeli Produk Rokok Merek A Mild di Surabaya. Jurnal Ilmu Sosial dan Politik. Vol. 21 No. 2 Desember 2010

Raheem, A. R., Vishnu, P., \& Ahmed, A. M. 2014. Impact of Product Packaging on Consumer's Buying Behavior. European Journal of Scientific Research, 122(2).

Sugiyono. 2008. Statistik untuk Penelitian. Bandung; Alfabeta.

Th Susetyarsi. 2012. "Kemasan Produk ditinjau dari Bahan Kemasan, Bentuk Kemasan dan Pelabelan pada Kemasan Pengaruhnya Terhadap Keputusan Pembelian pada Produk Minium Mizone di Kota Serang".

Titik Wijayanti. 2012. Management Marketing Plan. Jakarta: PT. Elex Media Komputindo 
Tjiptono, Fandy. 2002. Strategi Pemasaran. Yogyakarta: Penerbit Andi Tommy Kurniawan Njoto. 2016. Pengaruh Desain Kemasan, Cita Rasa dan Variasi Produk Terhadap Keputusan Pembelian Konsumen pada Bumi Anugerah, Performa : Jurnal Manajemen dan strat-uo bisnis, Volume 1 Nomor 4. 